\title{
Government-Linked Investment Companies and Real Earnings Management: Malaysian Evidence
}

\author{
Rahayu Abdul Rahman ${ }^{1}$, Asheq Rahman², Erlane K Ghani ${ }^{3}$ \& Normah Hj Omar ${ }^{3}$ \\ ${ }^{1}$ Accounting Research Institute and Faculty of Accountancy, Universiti Teknologi MARA, Perak, Malaysia \\ ${ }^{2}$ Department of Accounting, Auckland University of Technology, Auckland, New Zealand \\ ${ }^{3}$ Accounting Research Institute, Universiti Teknologi MARA, Selangor, Malaysia \\ Correspondence: Rahayu Abdul Rahman, Accounting Research Institute and Faculty of Accountancy, Universiti \\ Teknologi MARA, Tapah Campus, 35400, Tapah Road, Perak, Malaysia.
}

Received: April 20, 2019

doi:10.5430/ijfr.v10n3p299
Accepted: May 7, 2019

Online Published: May 19, 2019

URL: https://doi.org/10.5430/ijfr.v10n3p299

\begin{abstract}
This study examines the association between government-linked investment companies' (GLICs') shareholdings and real earnings management activities in Malaysia. Consistent with prior research, this study uses three proxies to measure real earnings management; abnormal cash flow from operations (RCFO), abnormal production costs (RPC), and abnormal discretionary expenses (RDE). This study segregates GLICs' shareholdings into two categories; Federal Government Pension Investment Funds (FGPIF) and other GLICs (OFGLIC). Using a sample of 213 firm-year observations of Malaysian government-linked companies from 2010 to 2015, this study finds that FGPIF is a more effective monitoring mechanism than OFGLIC in limiting real earnings management. The findings also show that there is a significant and negative relationship between Employee Provident Fund (EPF), Khazanah Nasional Berhad (Khazanah), Permodalan Nasional Berhad (PNB) and RCFO and RPC. The evidence suggests that these three are the most effective government institutional investors in promoting corporate governance, which in turn limit real earning management activities in Malaysia. In general, the findings support the incentive alignment hypothesis, which argues that companies with government intervention are normally better governed.
\end{abstract}

Keywords: government ownership, government linked investment companies, real earnings management, institutional investors, Malaysia

\section{Introduction}

Prior studies have highlighted that government institutional investors play an important role in controlling managerial moral hazard including earnings management (Ding, Zhang \& Zhang, 2007; Har, Majdi \& Mohammed, 2012; Jamaludin, Mohd-Sanusi \& Kamaluddin, 2015; Jow, Loo, Zainal-Abidin, Noordin \& Ariffin, 2007). In general, there are two competing views on the effects of government institutional ownership on companies' earnings management practices. According to the incentive alignment argument, companies controlled by government institutional investors are normally better governed (Ang \& Ding, 2006; Lau \& Tong, 2008) and more politically sensitive (Mohd Ghazali, 2007). More specifically, the activities of these firms are not only under the watchful eyes of the public, i.e., the investors and shareholders, but also the government. As a result, the management of these firms is more conscious of the importance of maximising shareholders' value over self-interest, which might limit managerial opportunism (Lau \& Tong, 2008; Morgan \& Alcocer 2017).

On the other hand, Wang (2002) contends that government intervention is the main factor for the inefficiency of state shareholdings, resulting from poor governance practices and greater agency problems. Ding et al. (2007) argue that the agency problems in state-owned firms are more complex than in privately-owned firms because there is an extra agency relationship in such firms as the controlling owners are themselves agents of the true owners i.e., the state. In particular, there is the agency cost between the state and the controlling owner, in addition to the agency cost between the controlling owner and minority shareholders. Further, Jow et al. (2007) argue that unlike owner-managers, who have to risk their own resources, government-linked companies' (GLCs) managers are using public funds as their major resources. The nature of their compensation, which is directly tied to accounting numbers, creates more incentive for top management to manage the reported earnings in order to maximise their compensation. 
Consistent with these conflicting theories, previous research on the relationship between government ownership and earnings management has provided mixed results (see for example, Jow et al, 2007; Hoang et al., 2014; Chen et al., 2003; Wang \& Yung, 2011; Har et al, 2012; Nejad, Agha \& Zadeh 2017). This study contributes to the current debate on the alignment versus entrenchment effect of the government institutional investor's ownership by investigating whether such ownership could be associated with a lower degree of earnings management.

This paper focuses on Malaysia as a country that provides an ideal setting to examine the effects of government institutional ownership on earnings management. Government institutional investors, which are also known as government-linked investment companies (GLICs), are a strong feature of the Malaysian corporate sector. Currently, there are seven GLICs, including the Employee Provident Fund (EPF), Khazanah Nasional Berhad (Khazanah), Kumpulan Wang Amanah Pencen (KWAP), Lembaga Tabung Angkatan Tentera (LTAT), Lembaga Tabung Haji (LTH), Menteri Kewangan Diperbadankan (MOF) and Permodalan Nasional Berhad (PNB). The Malaysian government, via its GLICs, owns the majority stake of the listed firms in several key industries such as electricity, telecommunications, postal services, airlines, airports, public transport, water and sewerage, banking and financial services. According to Jow et al. (2007), companies controlled by GLICs represent approximately 40 per cent of the market capitalisation of the Malaysian stock market.

This study is an extension of that of Bin-Muhamed (2013), who examined the impact of GLICs on earnings management via discretionary accounting accruals. This study examines earnings management via real activities because such practices have recently been significantly higher in Malaysia (Zamri et al., 2013; Suffian et al., 2015; Sulong et al., 2014; Haji-Abdullah \& Wan-Hussin, 2015; Abdul Rahman, 2012) and in most other countries (Roychowdhury, 2006; Cohen \& Zarowin, 2010). Graham, Harvey and Rajgopal (2005) argue that managers prefer real activities manipulation to accrual earnings management. They reported that 80 percent of survey participants in their study took economic actions such as reducing discretionary expenses on research and development (R\&D), advertising and maintenance in order to meet an earnings target. According to Roychowdhury (2006), although real earnings management (REM) might reduce a firm's value, managers are more willing to manage earnings through real activities, as such practices are less likely to draw auditor or regulatory scrutiny. In the Malaysian context, Salleh (2009) provides similar findings. He found that a majority of survey participants who had experienced missing an earnings target preferred to make economic sacrifices rather than manipulate accounting figures. One of the participants in Salleh's study said: "We sit down in our third quarter meeting, look into the figures then try to reduce expenses like advertising, travelling and R\&D. These actions are within our control" (p.166). Thus, the main objective of this paper is to examine the impact of GLICs' ownership on real earnings management practices.

Second, we examine the impact of two main groups of GLIC shareholdings; Federal Government Pension Investment Funds (FGPIF) and other GLICs (OFGLIC), on real earnings management. Prior studies argue that the effectiveness of institutional investors' monitoring functions is dependent on the nature of their investment horizons (Bushee, 1998; Koh, 2007), the constraints to which they are subjected, their objectives, and their preferences for liquidity (Gillan \& Starks, 2000). Bin-Muhamed (2013) stresses that these two main groups of GLICs in Malaysia have different objectives, investment strategies and control structures. He argues that FGPIF has clearer objectives than its counterpart, OFGLIC. The main objective of FGPIF is to provide retirement benefits or maximize savings returns for its members in an efficient and reliable manner. In contrast, OFGLIC is a trustee for the country's commercial assets, with the main objective of promoting the federal government's economic and social policies. While OFGLIC's board is chaired by the Prime Minister and consists of government representatives, FGPIF's board is dominated by representatives of its depositors and specialist advisors. Bin-Muhamed (2013) argues that government representatives are constrained by time and business skills as well as experience, which limits their ability to supervise and control OFGLIC. Thus, with clearer objectives and effective board monitoring, FGPIF is expected to have more incentive and ability to deter earnings management because such an activity can negatively affect its long-term investment performance.

Third, this study examines the impact of each GLIC on real earnings management. In 2004, the Malaysian government introduced various initiatives and measures to instil better governance practices in GLICs and their investee companies. For example, in 2007, the Guide of Best Practices for Institutional Investors was issued, setting out how GLICs should discharge their responsibilities on behalf of their beneficiaries and other stakeholders to influence, guide and monitor investee companies in a responsible way. In fact, each GLIC has its own strategies for exercising influence over its investee companies and holding them accountable for good governance. For example, the EPF, as a leading retirement savings fund in Malaysia, has taken numerous initiatives in promoting and ensuring more effective corporate governance standards in its investee companies. Among the initiatives undertaken are dialogues with the regulators, the Securities Commission and Bursa Malaysia; continuous engagement with the 
investee companies, which emphasize performance and corporate governance; and most recently, the introduction of the EPF's Corporate Governance Principles and Voting Guidelines. This booklet, which emphasises the accountability, integrity and transparency of the board of directors and disclosures such as size and composition of the board, separation of power between chairman and CEO, re-election of directors, authority to allot and issue shares, employee share option schemes, related-party transactions and dividend policy, provides guidelines to the EPF and its investee companies. In addition, members of the Minority Shareholder Watchdog Group (MSWG), EPF, LTAT, LTH and PNB play proactive roles to enhance shareholder activism and to protect minority shareholders' interests. MSWG plays a significant role in corporate governance in mitigating the problems associated with conflict between controlling owners and minority shareholders in Malaysia. For public companies, MSWG is regarded as one of the ways to discipline, scrutinize, and monitor management. The main objectives of MSWG are to monitor breaches of and non-compliance with corporate governance practices and to limit the use of unethical or questionable practices by the management of public listed companies. With regards to Khazanah, it plays a critical role in accelerating the GLC Transformation Programme (GLCT). As a secretariat of the programme and the Putrajaya Committee on GLIC High Performance, Khazanah helps to ensure that all the ten GLCT initiatives succeed. One of the initiatives is to enhance GLIC monitoring and management functions to transform GLCs into high-performing and commercially driven entities. These differences matter in examining the impact of each GLIC on real earnings management.

Based on a sample of 213 firm-year observations of Malaysian GLCs from 2010 to 2015, we found evidence of a negative relationship between GLICs' ownership and REM measures. In particular, the results show a significant negative association between FGPIF and two measures of REM; RCFO and RDE. Further, the results also indicate a negative relationship between OFGLIC and RPC. These findings suggest that FGPIF plays a more effective role in monitoring its portfolio firms than OFGLIC. This study also provides additional analysis to reflect the heterogeneity in GLICs, and found that Khazanah, EPF and PNB play important roles in reducing real earnings management in their portfolio companies. Specifically, firms with higher Khazanah, EPF and PNB shareholdings are less likely to manage their reported earnings via abnormal cash flow from operations and abnormal discretionary expenses.

This paper makes multifaceted contributions. First, the study expands on the existing body of knowledge on the relationship between government ownership and the level of earnings management. This is an extension of prior studies on government ownership influence on accrual earnings management (Har et al., 2012; Jamaludin et al., 2015; Jow et al., 2007). It examines the impact of government ownership on another aspect of earnings management activities; real earnings management. Second, we add to the literature on heterogeneity in GLICs by showing the type of GLIC monitoring that matters for REM activities.

The remainder of the paper is organized as follows. Section two provides a brief description of Malaysian GLICs. Section three draws a connection between earnings management and government ownership and develops the research hypothesis. Section four elaborates the research design. Section five presents and discusses the findings. The final section provides the summary and conclusions.

\section{Institutional Background: Malaysian Government-Linked Investment Companies (GLICs)}

In Malaysia, GLICs are the investment arms of the government in allocating some or all of their funds to publicly listed companies on Bursa Malaysia, which are known as Government-Linked Companies (GLC). As previously explained, there are seven GLICs, whose functions are as follows; EPF is a Malaysian government agency, which is incorporated under the Employees Provident Fund Act 1991 (Act 452). The main objective is to manage the compulsory savings plan and retirement planning for private sector workers in Malaysia and provide retirement benefits for its members through management of their savings in an efficient and reliable manner. Khazanah was incorporated under the Companies Act 1965 on 3 September 1993 and plays an important role in holding and managing the commercial assets of the government in pursuing Malaysia's long term economic interests. LTAT was established by an Act of Parliament (Act 101, 1973). As a government statutory body, LTAT provides retirement benefits and a savings scheme for officers of Angkatan Tentera Malaysia. KWAP or the Retirement Fund (Incorporated), was incorporated on 1st March 2007 under the Retirement Fund Act 2007. The objective of KWAP is to assist the federal government in funding its pension liabilities. TH was incorporated in 1962 as a government initiative for the welfare of Muslims in Malaysia who wish to perform the Haj. TH facilitates Malaysian Muslims both in savings and by investing in Shariah-compliant financial instruments. MOF was established pursuant to the Ministry of Finance (Incorporation) Act 1957. In general, it aims to manage the nation's finances and economy effectively, transparently and efficiently to achieve Malaysia's development goals and improve the quality of life and social wellbeing. The final GLIC is PNB, which is the biggest investment fund management company in Malaysia. It 
was incorporated on 17 March 1978 to support the Government's New Economic Policy in promoting share ownership among the Bumiputera and to develop opportunities for deserving Bumiputera professionals to participate in the creation and management of wealth. Consistent with Bin-Muhamed (2013), we separate the GLICs into two main categories; Federal Government Pension Investments Fund Companies (FGPIF) and Other Federal Government Investment Companies (OFGLIC). The categories are based on the nature and objectives of each GLIC. FGPIF consists of EPF, KWAP, LTAT, TH and PNB, as these GLICs have the same main objectives; management of retirement funds and savings plan for their depositors. In contrast, OFGLIC includes Khazanah and MOF, which play significant roles in managing the country's assets.

\section{Literature Review}

\subsection{Earnings Management and Government Ownership}

Healy and Wahlen (1999) defined earnings management as opportunistic behaviour. It occurs when managers use judgment in financial reporting to alter accounting numbers to either mislead stakeholders about the underlying economic performance of the company or to influence contractual outcomes. According to Fields, Lys and Vincent (2001), managers can influence reported accounting numbers by managing accounting choices either via accruals (hereafter referred to as accrual earnings management (AEM)) or real-based transactions (hereafter referred to as real earnings management (REM)). The former refers to earnings management activities that have no direct cash flow implications. For example, they may include the decision to write down assets, to recognize or defer revenues, to capitalize or expense certain costs such as repair expenditures, and the timing of adoption of new standards. REM occurs when managers use real economic actions that affect cash flows to produce the desired earnings (Dechow \& Schrand, 2004, Fields, Lys \& Vincent, 2001). Examples of REM include reductions in discretionary spending such as research and development $(\mathrm{R} \& \mathrm{D})$, advertising and maintenance expenditures, aggressive price discounts to increase sales volumes, overproduction to report lower cost of goods sold (COGS), and repurchasing of common shares.

A review of the literature on the impact of government ownership on opportunistic earnings management showed mixed empirical results. For example, consistent with the management entrenchment effect hypothesis, Chen et al. (2003) find that local government has a significant positive relationship with the earnings management practices of listed firms in order to meet the regulations stipulated by central government. Further, Ding et al. (2007) ; Myeni \& Mvuyana (2018) examine earnings management practices in Chinese state-owned listed firms. This study reveals that such firms are more likely to manage earnings via operating-related accrual mechanisms and non-operating transactions with related parties.

Ben-Nasr et al. (2015) examine whether state ownership affects earnings quality. They hypothesize that government has more incentives to tunnel corporate resources and expropriate other shareholders for political benefits. To hide this expropriation, the government may lead managers to manipulate earnings, which results in a lower quality of accounting earnings. Using 350 firms from 45 countries, they find that state ownership is associated with greater abnormal accruals, lower earnings informativeness and more transitory earnings. The results indicate that state ownership is associated with lower earnings quality than their non-government owned counterparts.

However, some scholars cast doubt on the entrenchment effect of government ownership on opportunistic earnings management (Hoang et al., 2014; Wang \& Yung, 2011; Jow et al., 2007). For example, Wang and Yung (2011) examine the impact of state ownership on earnings management in China. The results show that state-owned firms have lower levels of earnings management than privately owned firms. This indicates that government plays an important role in mitigating management pressure to manipulate earnings numbers.

In a related study but using Vietnamese data, Hoang et al. (2014) investigate the impact of state ownership on earnings management of listed firms on the Ho Chi Minh Stock Exchange and the Hanoi Stock Exchange. The findings suggest that state ownership limits opportunistic earnings management by accrual accounting choices.

In the Malaysian context, Jow et al. (2007) investigate the prevalence of earnings management between GLCs and Chinese family-linked companies. They argue that the motive of GLCs to manage reported earnings is related to managerial compensation plans, as their managers' compensation is tied directly to accounting results. On the other hand, the motive of Chinese family-linked firms to engage in income-decreasing earnings management might be attributed to tax-related issues, as management attempts to minimise taxable income and improve cash flows. However, the results show that there is a negative relationship between concentration of shareholdings and earnings management in GLCs. This indicates that GLCs are less likely to manage earnings numbers via abnormal accruals. Recently, Bin-Muhamed (2013) investigated the impact of FGPIF, OFGLIC and State ownerships on earnings management via discretionary accounting accruals. The findings show an insignificant negative association between 
both FGPIF and OFGLIC and accruals earnings management measures. In addition, he finds that only State ownership has a significant and negative relationship with accruals earnings management measures. He concludes that the objectives and control structures of GLICs do not affect earnings management activities in Malaysia.

\subsection{Hypotheses Development}

Despite the mixed results for the relationship between government ownership and earnings management, this study attempts to extend the findings of Bin-Muhamed (2013) by examining the impact of government ownership (FGPIF and OFGLIC) on another type of earnings management; real earnings management. This study examines the degree of real earnings management instead of accruals earnings management because of recent studies highlighting the fact that companies all over the world have tended to switch from accruals to real earnings management as such practices are likely to be harder to detect (Cohen et al., 2008; Nxumalo \& Naidoo 2018). In 2004 the Malaysian government embarked on a transformation initiative to restructure GLCs and GLICs. The transformation has been monitored by a government agency called the Putrajaya Committee on GLC (PCG). The transformation policy highlights ten initiatives: (1) enhance board effectiveness; (2) strengthen directors' capabilities; (3) enhance GLICs' monitoring and managerial functions; (4) improve regulatory improvement; (5) clarify social obligations; (6) review and revamp procurement; (7) optimize capital management practices; (8) manage and develop leaders and other human capital; (9) intensify performance and management practices; and (10) enhance operational improvement. In other words, the GLICs, both FGPIF and OFGLIC, are explicitly charged with improving the corporate governance of their portfolio companies. Therefore, it is expected that companies controlled by GLIC shareholdings are less likely to be engaged in real earnings management. Based on this notion, this study hypothesises that:

$\mathrm{H}_{1 \mathrm{a}}$ : Control by FGPIF has a significant and negative association with real earnings management.

$\mathrm{H}_{1 \mathrm{~b}}$ : Control by OFGLIC has a significant and negative association with real earnings management.

Bin-Muhamed (2013) argues that FGPIF might have more incentive to deter earnings management in their portfolio companies as their investments are long-term, aiming to provide continuing benefits to their depositors or unit holders. He adds that FGPIF has a clearer objective, which is to maximise depositors' wealth, while OFGLIC is highly influenced by the government in pursuing social and economic development objectives. In addition, OFGLIC's board of directors is dominated by government and senior politicians, including the Prime Minister, senior Ministers and civil servants. This group has constraints in time, skill and in experience in managing businesses. This limits their ability to supervise and control their portfolio companies. Therefore, this study hypothesises that:

$\mathrm{H}_{2}$ : FGPIF is a more effective monitor of real earnings management activities than OFGLIC.

\section{Research Design and Methodology}

\subsection{Sample Selection and Data Collection}

Our sample comprised non-financial firms controlled by GLICs listed on Bursa Malaysia for the period 2010 to 2015. The data on GLIC ownership and various governance variables were collected from the companies' annual reports. The data required for computing real earnings management and firms' specific characteristics as control variables were collected from Thompson Reuters' Datastream. We excluded firms controlled by GLICs in the banking and finance sector because they have different guidelines and governance systems (Abdul Rahman \& Mohamed Ali, 2006; Mungwari, 2018). We also excluded firm-year observations with missing real earnings management measures data or those with no annual reports. This procedure yielded 213 firm-year observations.

\subsection{Operationalisation of the Dependent, Independent and Control Variables}

\subsubsection{Dependent Variables: Real Earnings Management}

The central variable of this study is real earnings management, which is defined as the actions managers take that deviate from normal business practices (Roychowdhury, 2006; Cohen \& Zarowin, 2010; Moussa, 2018). Consistent with previous studies, we used three proxies to measure real earnings management: abnormal levels of cash flow from operations (RCFO); abnormal production costs (RPC); and abnormal discretionary expenses (RDE). The measurement of real earnings management used here is taken from a study by Roychowdhury (2006), which estimated RCFO, RPC and $\mathrm{RDE}$ as the residuals from the following model respectively.

$$
\mathrm{CFO}_{\mathrm{it}} / \mathrm{A}_{\mathrm{it}-1}=\beta_{1}\left[1 / \mathrm{A}_{\mathrm{it}-1}\right]+\beta_{2}\left[\operatorname{Sales}_{\mathrm{it}} / \mathrm{A}_{\mathrm{it}-1}\right]+\beta_{3}\left[\Lambda \mathrm{Sales}_{\mathrm{it}} / \mathrm{A}_{\mathrm{it}-1}\right]+\varepsilon_{\mathrm{it}}
$$

Where,

$\mathrm{CFO}_{\mathrm{it}}=$ Cash flow from operation in period $\mathrm{t}$

$\mathrm{A}_{\mathrm{it}-1}=$ Total assets of firm $\mathrm{i}$ in year $\mathrm{t}-1$; 
Sales $_{\mathrm{it}}=$ Sales of firm $\mathrm{i}$ in year $\mathrm{t}$

$\Lambda$ Sales $_{\mathrm{it}}=$ Sales of firm $\mathrm{i}$ in year $\mathrm{t}$ less revenues of firm $\mathrm{i}$ in year $\mathrm{t}-1$;

$\varepsilon_{\mathrm{it}}=\mathrm{A}$ residual term that captures the level of abnormal cash flow of firm $\mathrm{i}$ in year $\mathrm{t}$.

$$
\operatorname{PROD}_{\mathrm{it}} / \mathrm{A}_{\mathrm{it}-1}=\beta_{1}\left[1 / \mathrm{A}_{\mathrm{it}-1}\right]+\beta_{2}\left[\operatorname{Sales}_{\mathrm{it}} / \mathrm{A}_{\mathrm{it}-1}\right]+\beta_{3}\left[\Lambda \operatorname{Sales}_{\mathrm{it}} / \mathrm{A}_{\mathrm{it}-1}\right]+\beta_{4}\left[\Lambda \operatorname{Sales}_{\mathrm{it}-1} / \mathrm{A}_{\mathrm{it}-1}\right]+\varepsilon_{\mathrm{it}}
$$

Where,

PROD $_{i t}=$ The sum of cost of goods sold and change in inventory of firm $i$ in year $t$;

$\varepsilon_{\mathrm{it}}=\mathrm{A}$ residual term that captures the level of abnormal production cost of firm $\mathrm{i}$ in year $\mathrm{t}$.

$$
\operatorname{DISCEXP} \mathrm{it}_{\mathrm{it}} / \mathrm{A}_{\mathrm{it}-1}=\beta_{1}\left[1 / \mathrm{A}_{\mathrm{it}-1}\right]+\beta_{2}\left[\text { Sales }_{\mathrm{it}-1} / \mathrm{A}_{\mathrm{it}-1}\right]+\varepsilon_{\mathrm{it}}
$$

Where,

DISCEXP $_{\mathrm{it}}=$ The sum of R\&D expenses and SG\&A of firm $\mathrm{i}$ in year $\mathrm{t}$;

$\varepsilon_{\mathrm{it}}=\mathrm{A}$ residual term that captures the level of abnormal discretionary expenses of firm $\mathrm{i}$ in year $\mathrm{t}$.

4.2.2 Independent Variable: Government Linked Investment Companies' Ownership

The key independent variable in this study is GLIC ownership. The measurement of GLIC ownership is the total percentage of the company's shareholding belonging to EPF, Khazanah, KWAP, LTAT, TH, MOF and PNB. Consistent with Bin-Muhamed (2013), we separated the GLIC ownership into two categories; Federal Government Pension Investments Fund Companies (FGPIF) and Other Federal Government Investment Companies (OFGLIC). The category is based on the nature and objectives of each GLIC. FGPIF consists of the total percentage of ownership by EPF, KWAP, LTAT, TH and PNB. OFGLIC includes the total percentage of ownership by Khazanah and MOF.

\subsubsection{Control Variables}

To test the hypothesis, this study controlled the variables that could influence real earnings management. These control variables are classified into two categories: firm characteristics and board characteristics.

With regards to firm characteristics, first, the study controlled the multivariate analysis for firm size. Large firms often receive more media attention, have a higher analysts following and face regular political scrutiny (Ahmed \& Duellman, 2007; Watts \& Zimmerman, 1978). Therefore, they are less likely to manage their earnings upwards. Second, the study controlled for leverage. Firms with higher levels of debt have their earnings scrutinized by debt providers or their agents, e.g., trustees, so they would not inflate earnings to benefit their shareholders or managers at the expense of the debt providers through dividends and earnings-based compensations (Ahmed et al., 2002). Third, the study controlled for growth. The growth of firms is likely to produce higher accruals because of increased revenue-generating activities, such as credit sales. Fourth, the study controlled for profit. Abdul Rahman and Mohamed Ali (2006) note that firms with low performance (ROA) have more incentive to engage in earnings management. Fifth, the study controlled for audit quality. According to Wahab et al. (2007), higher quality auditors are more likely to ensure greater transparency and eliminate mistakes in financial statements since they are more anxious to protect their reputation. Therefore, we predict a negative association between audit quality and earnings management.

In line with prior research, this study controlled for board characteristics. First, the study controlled for board independence. Fama and Jensen (1983) theorise that the board of directors is the highest internal control mechanism, responsible for monitoring the actions of top management. However, they argue that the ability of the board to act as an effective monitoring mechanism depends on its independence from management. Independent directors are believed to be able to monitor managers as they have incentives to develop their reputations as experts in decision control (Agrawal \& Chadha, 2005). Thus, the presence of independent directors on the board is seen as a check and balance mechanism, enhancing a board's effectiveness and constraining opportunistic behaviour among managers. This study predicted a negative association between board independence and earnings management practices, as the theory suggests.

Secondly, the study controlled for board size. Jensen (1993) and Garcia-Meca and Ballesta (2009) suggest that the number of directors is one of the important factors in the effectiveness of a board. There are two views on this issue. Proponents of agency theory believe that a larger board has more opportunity to control and monitor the actions of management as it has a greater number of people with more expertise (Dalton et al., 1999), and valuable experience (Xie et al., 2003) to prevent or limit managerial opportunistic behaviour. Finkelstein and D'Aveni (1994) noted that a larger board has more problem-solving capabilities, as the burden facing the directors is equally shared among them.

Thirdly, the study controlled for audit-committee independence. Prior studies suggest that the effectiveness of an 
audit committee is due, in part, to the extent to which the committee is independent. Peasnell et al. (2005) failed to find evidence that the existence of an audit committee reduces the level of earnings management. This result suggests that the presence of an audit committee alone, without independent members, is less likely to be an effective monitor for managerial opportunism. Independence is considered an essential quality for an audit committee in fulfilling its oversight role as it allows both the internal and external auditors to remain free of undue influences and interference from management (Vicknair, Hickman \& Carnes, 1993).

Finally, the study controlled for CEO duality. CEO duality or the 'dominant personality' phenomenon occurs when the same person holds the two most dominant posts in the firm, namely those of CEO and chairman. Advocates of agency theory argue that CEO duality - which implies CEO dominance over the board-promotes CEO entrenchment and hence, can lead to opportunistic and inefficient behaviour that reduces shareholder wealth (Jensen \& Meckling, 1976). A year dummy and an industry dummy were also included in the study to control for year and industry effects.

\subsection{Multivariate Regression Models}

To test the research aims, we run the following regression models:

$$
\begin{gathered}
R C F O_{f t}=\alpha+\alpha_{1} \text { FGPIF } f t+\alpha_{2} \text { OFGLIC } f t+f(\text { control variables })+\xi \\
R P C_{f t}=\alpha+\alpha_{1} \text { FGPIF } f t+\alpha_{2} \text { OFGLIC } f t+f(\text { control variables })+\xi \\
R D E_{f t}=\alpha+\alpha_{1} \text { FGPIF } f_{t}+\alpha_{2} \text { OFGLIC } f t+f(\text { control variables })+\xi
\end{gathered}
$$

Where,

Dependent variables:

$\mathrm{RCFO}_{f t}=$ Abnormal cash flows of firm $f$ in year $t$,

$\mathrm{RPC}_{f t}=$ Abnormal production costs of firm $f$ in year $t$,

$\operatorname{RDE}_{f t}=$ Abnormal discretionary expenses of firm $f$ in year $t$,

Independent variables:

FGPIF $f t=$ Total percentage of shareholding by EPF, LTAT, TH, KWAP \& TH,

OFGLIC $f t=$ Total percentage of shareholding by Khazanah \& MOF,

Control variables:

BODIND $_{f t}=$ The proportion of independent directors on the board,

BODSIZE $_{f t}=$ The number of directors on the board,

$\operatorname{AUDIND}_{f t}=$ The proportion of independent directors on the audit committee,

AUDSIZE $_{f t}=$ The number of directors on the audit committee,

DUALITY $_{f t}=1$ if CEO is board chair and 0 otherwise,

SIZE $_{f t}=$ Natural log of total assets of firm $f$ in year $y$,

LEVERAGE $_{f t}=$ Total liabilities to total assets of firm $f$ in year,

GROWTH $_{f t}=$ Market to book ratio of firm $f$ in year $y$,

PROFIT $_{f t}=$ Earnings $($ EBIT) to total assets

BIG4 $f t=1$ if a firm is audited by Big- 4 audit firms and 0 otherwise,

YEAR $_{f t}=$ Year,

$\mathrm{IND}_{f t}=$ Industry.

\section{Results and Findings}

\subsection{Descriptive Analysis}

As reported in Table 1, RCFO, RPC, and RDE of the companies in the sample have mean absolute values of 0.70 , 0.79 , and 0.80 respectively. The findings indicate that on average, listed firms controlled by GLICs are more likely to manage their reported earnings by using abnormal discretionary expenses. The results also show that the largest shareholdings (mean of 19.67 per cent and maximum value of 87.35 per cent) in the sample belonged to Khazanah. 
Table 1. Descriptive statistics of the sample firms used in this study

\begin{tabular}{lllllll}
\hline & Min & Max & Mean & SD & Skew & Kurt \\
\hline Panel A:Experimental variables & & & & & & \\
\hline RCFO (residual) & -4.16 & 5.94 & 0.70 & 0.99 & 0.55 & 2.27 \\
\hline RPC (residual) & -2.60 & 3.08 & 0.70 & 0.99 & 0.22 & 0.20 \\
\hline RDE (residual) & -3.00 & 3.14 & 0.70 & 0.99 & 0.51 & 0.29 \\
\hline Absolute RCFO & 0 & 5.94 & 0.70 & 0.69 & 1.22 & 1.75 \\
\hline Absolute RPC & 0 & 3.08 & 0.79 & 0.59 & 1.15 & 1.63 \\
\hline Absolute RDE & 0 & 3.14 & 0.80 & 0.58 & 1.24 & 2.28 \\
\hline Khazanah ownership & 0 & 87.35 & 19.67 & 26.80 & 0.37 & 1.24 \\
\hline EPF ownership & 0 & 42.20 & 8.9 & 8.74 & 2.51 & 6.51 \\
\hline KWAP ownership & 0 & 86.81 & 5.94 & 19.16 & 1.62 & 4.03 \\
\hline LTAT ownership & 0 & 20.15 & 0.69 & 2.98 & 0.84 & 0.76 \\
\hline TH ownership & 0 & 71.80 & 6.21 & 17.25 & 2.96 & 7.64 \\
\hline MOF ownership & 0 & 69.86 & 2.63 & 10.64 & 1.61 & 2.20 \\
\hline PNB ownership & 0 & 56.03 & 4.87 & 14.58 & 2.11 & 3.31 \\
\hline FGPIF & 0 & 79.07 & 23.46 & 20.10 & 1.55 & 0.86 \\
\hline OFGLIC & 0 & 87.35 & 52.20 & 17.50 & 1.43 & 0.79 \\
\hline Panel B:Control variables & & & & & & \\
\hline SIZE & 10.92 & 18.52 & 15.43 & 1.68 & 0.63 & 1.21 \\
\hline LEVERAGE & 0.01 & 2.58 & 0.56 & 0.33 & 2.21 & 9.93 \\
\hline GROWTH & -0.49 & 7.60 & 1.72 & 1.02 & 2.03 & 7.91 \\
\hline PROFIT & -0.48 & 0.35 & 0.061 & 0.097 & 2.15 & 7.66 \\
\hline BODSIZE & 5 & 15 & 9 & 2.00 & 0.42 & 0.29 \\
\hline BODIND & 2 & 9 & 4 & 1.46 & 0.84 & 1.19 \\
\hline AUDSIZE & 3 & 6 & 4 & 0.70 & 0.67 & 2.15 \\
\hline AUDIND & 2 & 4 & 3 & 0.61 & 0.04 & 0.32 \\
\hline & & & & & & \\
\hline & & 0 & & & &
\end{tabular}

\subsection{Correlation Analysis}

Table 2 shows the Pearson correlations between REM measures, FGPIF ownership, OFGLIC ownership and various control variables. In general, FGPIF is negatively correlated to RDE at the one per cent significance level. With regards to OFGLIC, there is a significant and negative relationship between OFGLIC and RPC. Therefore, there is some preliminary support for the prediction that government institutional investors play effective roles in limiting real earnings management practices in their portfolio firms. However, there is also a positive and significant correlation between OFGLIC and RDE, which requires further analysis.

Table 2. Correlation analysis of REM proxies, FGPIF, OFGLIC and control variables

\begin{tabular}{|c|c|c|c|c|c|c|c|c|c|c|c|c|c|c|c|}
\hline Variables & RCFO & RPC & RDE & FGPIF & OFGLIC & SIZE & LEVERAGE & GROWTH & PROFIT & BIG4 & BODSIZE & BODIND & AUDSIZE & AUDIND & DUALITY \\
\hline RCFO & 1 & $-.543^{\prime \prime}$ & .053 & -.011 & -.103 & .102 & -.092 & .099 & $389^{\prime \prime}$ & .033 & .122 & $.164^{\circ}$ & .036 & .034 & -.046 \\
\hline RPC & & 1 & $-204^{\prime \prime}$ & -.027 & $-.099^{\circ}$ & $-.193^{\prime \prime}$ & $.146^{\circ}$ & .039 & $-.426^{\prime \prime}$ & .201 & .004 & .003 & .053 & .072 & .046 \\
\hline RDE & & & 1 & -314 & $.146^{\circ}$ & -.113 & -.074 & -.029 & .028 & -.064 & -.071 & -.125 & -111 & .004 & 000 \\
\hline FGPIF & & & & 1 & -.527 & -.088 & -.026 & -.143 & .060 & .107 & -.009 & .065 & $-.170^{\circ}$ & $-.170^{\circ}$ & .030 \\
\hline OFGLIC & & & & & 1 & $-.503^{\prime \prime}$ & $-.275^{\circ}$ & -.171 & $-.390^{\prime \prime}$ & .145 & $-325^{\prime \prime}$ & $-.442^{n}$ & -288 & -197 & .000 \\
\hline SIZE & & & & & & 1 & -.077 & $.255^{* 4}$ & $.293^{\circ \prime}$ & $.472^{\prime \prime}$ & $.429^{\prime \prime}$ & $.343^{*+1}$ & $.321^{\prime \prime}$ & $.320^{\circ}$ & -.123 \\
\hline LEVERAGE & & & & & & & 1 & -.060 & -.061 & -.133 & -.027 & $.182^{\prime \prime}$ & -.017 & .135 & -.043 \\
\hline GROWTH & & & & & & & & 1 & $.141^{\circ}$ & .075 & $.150^{\circ}$ & $.189^{\prime \prime}$ & .083 & $.242^{\prime \prime}$ & -.046 \\
\hline PROFIT & & & & & & & & & 1 & .074 & $.143^{\circ}$ & .086 & $.152^{\circ}$ & $228^{* 1}$ & $-.272^{* 4}$ \\
\hline BIG4 & & & & & & & & & & 1 & -.111 & .086 & -.075 & $-146^{\circ}$ & .028 \\
\hline BODSIZE & & & & & & & & & & & 1 & $639^{\prime \prime}$ & $.469^{\prime \prime}$ & $.469^{\circ \prime}$ & -.096 \\
\hline BODIND & & & & & & & & & & & & 1 & $.221^{\prime \prime}$ & $481^{\prime \prime}$ & -.049 \\
\hline AUDSIZE & & & & & & & & & & & & & 1 & $.641^{\prime \prime}$ & -.072 \\
\hline AUDIND & & & & & & & & & & & & & & 1 & -104 \\
\hline DUALITY & & & & & & & & & & & & & & & 1 \\
\hline
\end{tabular}

Note: This table provides correlation matrix for explanatory variables.

***Statistical significance at the $1 \%$ level; ** Statistical significance at the 5\% level; * Statistical significance at the $10 \%$ level. 


\subsection{Multivariate Analysis}

Ordinary least squares procedures (OLS) were used to estimate the models stated in Section 5.3. The results of the above models are reported in the following subsections.

\subsubsection{REM Measures and GLICs Ownership and Control Variables}

Table 3 reports the results of the regression estimation of GLIC ownership on the REM measures. As expected in $H_{l a}$, the results show that FGPIF has a significant negative association with two proxies for REM; RCFO and RDE. The findings also support $H_{l b}$. In particular, the results show a significant negative association between OFGLIC and REM's proxy, RPO. Thus, these findings support $H_{2}$ and suggest that firms owned by FGPIF are less likely to be engaged in REM. This is in line with the argument put forward by Bin-Muhamed (2013) that FGPIF is a better monitor than OFGLIC. According to Bin-Muhamed, FGPIF consists of long-term institutional investors, aiming to provide continuing benefits to their depositors. OFGLIC's board of directors is appointed by the government and dominated by senior politicians who have constraints in terms of both time and business experience. This in turn limits their ability to monitor their portfolio firms. Given that FGPIF might have more incentives to deter earnings management in their portfolio firms, in general, the findings are consistent with those of Hoang et al. (2014), Wang and Yung (2011) and Jow et al. (2007), who find that government-owned firms are less likely to be involved in earnings management. These results support previous arguments in the alignment hypothesis that government ownership is an effective monitoring mechanism in limiting managerial opportunism in business organizations, which in turn increases the quality of accounting numbers.

With regard to the control variables included in this study, Table 3 shows a significant negative association between RPC and SIZE. This implies that larger firms are less likely to use abnormal production costs in managing reported earnings. This result is consistent with previous research by Ahmed and Duellman (2007) and Watts and Zimmerman (1978), who argue that large firms are less likely to manage their reported earnings as they often receive more media attention, have a higher analyst following and face regular political scrutiny. In addition, Table 3 reveals a significant positive relationship between GROWTH and RPC. The finding suggests that high-growth firms in Malaysia are more motivated to engage in earnings management using abnormal production costs. This result supports the argument by Chen et al. (2015) that high-growth firms have relatively stronger incentives to manage earnings in order to meet earnings targets. The findings also reveal that PROFIT is significant and contributes to explaining REM practices within the country studied. Although the results indicate that firms with better performance are less likely to use abnormal production costs, such firms are, however, motivated to use abnormal cash flow from operations in managing their accounting numbers. This indicates that one cannot assume that firms with better performance are less motivated to engage in earnings management, as Healy and Wahlen (1999) and Abdul Rahman and Mohamed Ali (2006) suggest. This is an issue that needs more investigation, as it indicates that firms with higher profits might use different types of REM to manage earnings.

For the remaining set of control variables, the findings indicate that RDE is positively related to BODSIZE. This result thus supports Lipton and Lorsh (1992) and Jensen (1993), who argue that a larger board is less likely to function effectively, because the ability to process problems competently reduces as board size increases (Jensen, 1993). Hermalin and Weisbach (2001) also assert that a larger board size may make it difficult for members to use their knowledge and skills effectively because of the issues involved in coordinating their contributions. In addition, Table 3 shows that AUDSIZE is negatively and significantly related to the REM measures RPC and RDE, suggesting that firms with more audit committee members are less likely to manage earnings via abnormal production costs and abnormal discretionary expenses. With regard to the composition of independent board and audit committee members, Table 3 shows conflicting results on the association between BODIND, AUDIND and REM proxies. In particular, there is a significant negative relationship between RDE and BODIND. The findings are in line with the argument put forward by Osma (2008) that more independent board members constrain the manipulation of R\&D expenditure as they have sufficient technical knowledge to identify opportunistic reductions in R\&D, and efficiently constrain opportunistic R\&D spending. However, contrary to expectation, the results also indicate that firms with a higher composition of independent non-executive directors on the board are motivated to engage in RCFO. In term of AUDIND, the findings suggest that higher numbers of independent audit committee members limit management involvement in RCFO but motivate such firms to manage earnings numbers by using abnormal production costs and abnormal discretionary expenses. This is in line with Abdul Rahman and Mohamed Ali (2006), who argue that independent directors in Malaysian firms have not been effective in carrying out their monitoring functions. According to them, the ineffectiveness of independent directors in Malaysia in discharging their monitoring duties may be due to lack of expertise, lack of the required skills and lack of knowledge of the business environment. 
Table 3. Regression analysis for FGPIF and OFGLIC

\begin{tabular}{|c|c|c|c|}
\hline Variables & Model (1) RCFO & Model (2) RPC & Model (3) RDE \\
\hline \multirow[t]{2}{*}{ FGPIF } & $-.007 * * *$ & .000 & $-.014 * * *$ \\
\hline & $(-1.777)$ & $(-.100)$ & $(-3.603)$ \\
\hline \multirow[t]{2}{*}{ OFGLIC } & -.003 & $-.005 * *$ & .002 \\
\hline & $(-1.211)$ & $(-1.891)$ & $(.801)$ \\
\hline \multicolumn{4}{|c|}{ Control Variables: } \\
\hline \multicolumn{4}{|c|}{ Firm's specific characteristics } \\
\hline \multirow[t]{2}{*}{ SIZE } & .023 & $-.072 *$ & -.071 \\
\hline & $(.418)$ & $(-1.373)$ & $(-1.211)$ \\
\hline \multirow[t]{2}{*}{ LEVERAGE } & -.187 & .227 & -.102 \\
\hline & $(-.913)$ & $(1.160)$ & $(-.466)$ \\
\hline \multirow[t]{2}{*}{ GROWTH } & .015 & $.093 *$ & -.018 \\
\hline & $(.234)$ & $(1.509)$ & $(-.264)$ \\
\hline \multirow[t]{2}{*}{ PROFIT } & $4.129 * * *$ & $-4.696 * * *$ & .935 \\
\hline & $(5.873)$ & $(-6.918)$ & $(1.248)$ \\
\hline \multirow[t]{2}{*}{ BIG4 } & -.113 & -.005 & .138 \\
\hline & $(-.450)$ & $(-.022)$ & $(.517)$ \\
\hline \multicolumn{4}{|c|}{ Control Variables: } \\
\hline \multicolumn{4}{|c|}{ Firms' board characteristics } \\
\hline \multirow[t]{2}{*}{ BODSIZE } & .016 & .058 & $.091 *$ \\
\hline & $(.302)$ & (1.179) & (1.647) \\
\hline \multirow[t]{2}{*}{ BODIND } & $.135^{* *}$ & -.068 & $-.133 * * *$ \\
\hline & $(2.062)$ & $(-1.089)$ & $(-1.900)$ \\
\hline \multirow[t]{2}{*}{ DUALITY } & .959 & -1.053 & .509 \\
\hline & (1.020) & $(-1.175)$ & $(.508)$ \\
\hline \multirow[t]{2}{*}{$\overline{\text { AUDSIZE }}$} & .116 & $-.268 * *$ & $-.324 * * *$ \\
\hline & $(.926)$ & $(-2.232)$ & $(-2.417)$ \\
\hline \multirow[t]{2}{*}{ AUDIND } & $-.386 * * *$ & $.465^{* * *}$ & $.317 * *$ \\
\hline & $(-2.387)$ & (3.017) & (1.836) \\
\hline \multirow[t]{2}{*}{ Intercept } & -.281 & .661 & $1.218^{* *}$ \\
\hline & $(-.420)$ & (1.032) & $(1.708)$ \\
\hline Observations & 213 & 213 & 213 \\
\hline Durbin-Watson & 2.010 & 1.637 & 1.432 \\
\hline R-Square & 20.80 & 29.10 & 15.40 \\
\hline Adjusted R-Square & 16.00 & 24.70 & 10.20 \\
\hline
\end{tabular}

Note: $* * *$ Statistical significance at the $1 \%$ level; $* *$ Statistical significance at the $5 \%$ level; $*$ Statistical significance at the $10 \%$ level.

\subsubsection{Additional Analysis}

Additional analysis was undertaken to examine which types of GLICs are effective in limiting real earnings management activities. Since each GLIC has different goals and investment strategies, we regressed each component against REM measures. The results in Table 5.4 indicate that Khazanah, EPF, LTAT and PNB are significantly related with RCFO at the five per cent level. The evidence suggests that only four government institutional investors are effective in monitoring earnings management activities via abnormal cash flows from operations. In addition, Model 2 in Table 4 shows a significant positive relationship between RPC and two GLICs; LTAT and KWAP, indicating that their investee firms are more likely to engage in abnormal production costs. Table 4 also shows a 
significant and negative relationship between RDE and six GLICs; Khazanah, EPF, LTAT, KWAP, TH and PNB. The findings suggest that most GLICs are more focused on RDE types of manipulation in their monitoring strategies as such manipulation is common in Malaysia. According to Salleh (2009), Malaysian listed firms are more likely to reduce expenses such as advertising, travel and $R \& D$ in managing reported earnings, as such expenditures are within management control. In a nutshell, the results suggest that the three main institutional investors in Malaysia Khazanah, EPF and PNB - play the most proactive role in limiting two types of REM; RCFO and RDE. This finding is consistent with their commitment to ensure high levels of accountability and transparency and to promote best practices in corporate governance among their investee companies through various programmes led by them, including MSWG's initiatives and the GLC Transformation Programme.

Table 4. Regression analyses for each GLIC

\begin{tabular}{llll}
\hline Variables & Model (1) RCFO & Model (2) RPC & Model (3) RDE \\
\hline Khazanah & $-.006^{* *}$ & .000 & $-.006^{* *}$ \\
& $(-1.624)$ & $(-.125)$ & $(-1.926)$ \\
EPF & $-.020^{* *}$ & .011 & $-.027^{* * *}$ \\
& $(-2.015)$ & $(1.180)$ & $-2.661)$ \\
\hline LTAT & $-.007^{* *}$ & $.012^{* * *}$ & $-.025^{* * *}$ \\
& $(-1.582)$ & $(2.611)$ & $(-5.384)$ \\
\hline KWAP & .012 & $.031^{*}$ & $-.035^{* *}$ \\
& $(.532)$ & $(1.448)$ & $(-1.624)$ \\
\hline TH & .003 & -.003 & $-.010^{* *}$ \\
& $(.599)$ & $(-.480)$ & $(-1.766)$ \\
MOF & -.004 & .004 & -.004 \\
& $(-.599)$ & $(.679)$ & $(-.644)$ \\
PNB & $-.008^{* *}$ & .003 & $-.029^{* * *}$ \\
& $(-1.540)$ & $(.690)$ & $(-5.747)$ \\
\hline
\end{tabular}

Control Variables:

Firm's specific characteristics

\begin{tabular}{llll}
\hline SIZE & .078 & $-.138^{* *}$ & $-.029^{* * *}$ \\
& $(1.212)$ & $(-2.258)$ & $(-.459)$ \\
\hline LEVERAGE & -.076 & .182 & -.226 \\
& $(-.350)$ & $(.888)$ & $(-1.056)$ \\
\hline GROWTH & .003 & $.147^{* *}$ & $-.132^{* *}$ \\
& $(.042)$ & $(2.255)$ & $(-1.937)$ \\
\hline PROFIT & $4.157^{* * *}$ & $-4.517^{* * *}$ & $.986^{*}$ \\
& $(5.786)$ & $(-6.595)$ & $(1.389)$ \\
\hline BIG4 & -.004 & -.188 & .423 \\
& $(-.017)$ & $(-.724)$ & $(1.581)$ \\
\hline Control Variables: & & & \\
Firms' board characteristics & & & \\
\hline BODSIZE & .033 & .067 & .053 \\
& $(.573)$ & $(1.240)$ & $.930)$ \\
\hline BODIND & .055 & .004 & $-.212^{* * *}$ \\
& $(.700)$ & $(.051)$ & $-2.713)$ \\
\hline DUALITY & .974 & -.914 & -.030 \\
& $(1.031)$ & $(-1.026)$ & $-.032)$ \\
\hline AUDSIZE & .058 & $-.214^{* *}$ & $-.448^{* * *}$ \\
\hline
\end{tabular}




\begin{tabular}{llll}
\hline & $(.441)$ & $-1.709)$ & $-3.430)$ \\
\hline AUDIND & $-.260^{*}$ & $.332^{* *}$ & $.575^{* * *}$ \\
& $(-1.537)$ & $(2.071)$ & $(3.433)$ \\
\hline Intercept & -1.067 & $1.278^{*}$ & $1.526^{* *}$ \\
& $(-1.219)$ & $(1.532)$ & $(1.764)$ \\
\hline Observations & 213 & 213 & 213 \\
\hline Durbin-Watson & 2.009 & 1.697 & 1.668 \\
\hline R-Square & 23.00 & 32.40 & 29.20 \\
\hline Adjusted R-Square & 16.10 & 26.30 & 22.90 \\
\hline
\end{tabular}

Note: ***Statistical significance at the $1 \%$ level. $* *$ Statistical significance at the $5 \%$ level. * Statistical significance at the $10 \%$ level.

\section{Summary and Conclusion}

The purpose of this paper was to examine the association between GLICs' shareholdings and real earnings management. To capture real earnings management, the study used three different measures: abnormal cash flows, abnormal production costs, and abnormal discretionary expenses, as developed by Roychowdhury (2006). The study used a sample of 213 Malaysian firms controlled by GLICs from 2010 to 2015.

Overall, the results of the study support the alignment hypothesis view that government ownership, via its institutional investors, limits real earnings management. In particular, the findings indicate that there is a significant negative relationship between FGPIF and two measures of real earnings management; RCFO and RDE. In addition, there is a significant and negative association between OFGLIC and RPC. The results suggest that Malaysian government institutional investors are effective monitors of real earnings management for their portfolio firms. The results also suggest that different objectives, control structures and investment strategies matter in real earnings management activities. The study also provides evidence that Khazanah, EPF and PNB are the most effective government institutional investors in Malaysia in limiting managerial opportunism. This finding suggests that the more active GLICs are in supporting government initiatives on corporate governance, the more effective is the monitoring role of institutional investors.

Overall, the results of this study have implications for both the theory and practice of corporate governance. This is the first study to examine two categories of GLICs - FGPIF and OFGLIC - to explain real earnings management practices among Malaysian GLCs. Thus, the results provide support for establishing a preliminary framework to empirically examine the effect of GLICs in limiting REM activities in Malaysia. The findings should also be of interest to regulators and the GLICs as they highlight the significant role played by such institutional investors in deterring REM. The effectiveness of the monitoring role, however, is subject to the commitment, objectives, control structures, investment strategies and business skills of GLICs' management and board members. Finally, these findings suggest that government efforts in promoting high level corporate governance among GLCs through various initiatives such as the introduction of MSWG, GLCT and the Corporate Governance Blueprint have had some positive impact on corporate governance practices, and thus limit managerial opportunism including REM activities.

This study is not without its limitations. First, this study examines only Malaysian GLCs listed on Bursa Malaysia and owned by the Malaysian federal government via GLICs. To provide more interesting and meaningful results, future studies could examine all Malaysian listed firms owned by federal and state governments. Second, this study only focuses on three types of REM. Another avenue for future research could be to use other proxies for measuring REM in order to test for the robustness of the results of this study.

\section{Acknowledgements}

This paper acknowledges the research funding contributed by the Ministry of Higher Education (MOHE).

\section{References}

Abdul Rahman, R. (2012). Religious ethical values and earnings quality: some evidence from Malaysia. Doctoral dissertation, Massey University, Albany, New Zealand.

Abdul Rahman, R., \& Haneem Mohamed Ali, F. (2006). Board, audit committee, culture and earnings management: Malaysian evidence. Managerial Auditing Journal, 21(7), 783-804. https://doi.org/10.1108/02686900610680549 
Agrawal, A., \& Chadha, S. (2005). Corporate governance and accounting scandals. Journal of Law and Economics, 48(2), 371-406. https://doi.org/10.1086/430808

Ahmed, A. S., \& Duellman, S. (2007). Accounting conservatism and board of director characteristics: An empirical analysis. Journal of Accounting and Economics, 43(2), 411-437. https://doi.org/10.1016/j.jacceco.2007.01.005

Ahmed, A. S., Billings, B. K., Morton, R. M., \& Stanford-Harris, M. (2002). The role of accounting conservatism in mitigating bondholder-shareholder conflicts over dividend policy and in reducing debt costs. The Accounting Review, 77(4), 867-890. https://doi.org/10.2308/accr.2002.77.4.867

Ang, J. S., \& Ding, D. K. (2006). Government ownership and the performance of government-linked companies: The case of Singapore. Journal of Multinational Financial Management, 16(1), 64-88. https://doi.org/10.1016/j.mulfin.2005.04.010

Ben-Nasr, H., Boubakri, N., \& Cosset, J. C. (2015). Earnings quality in privatized firms: The role of state and foreign owners. Journal of Accounting and Public Policy, 34(4), 392-416. https://doi.org/10.1016/j.jaccpubpol.2014.12.003

Bin-Muhamed, A. (2013). The impact of government linked investment companies in Malaysia on the performance and earnings management of their portfolio companies. Doctoral thesis, Durham University, Durham, UK. Retrieved from http://etheses.dur.ac.uk/9376/

Bushee, B. J. (1998). Institutional investors, long-term investment, and earnings management. International Journal of Economics and Management, 3(1), 204-223.

Chen, G., Luo, S., Tang, Y., \& Tong, J. Y. (2015). Passing probation: Earnings management by interim CEOs and its effect on their promotion prospects. Academy of Management Journal, 58(5), 1389-1418. https://doi.org/10.5465/amj.2013.0351

Chen, X., Lee, C. W. J., \& Li, J. (2003). Chinese tango: Government assisted earnings management. Working Paper, Tsinghua University, Beijing, China. https://doi.org/10.2139/ssrn.408800

Cohen, D. A., \& Zarowin, P. (2010). Accrual-based and real earnings management activities around seasoned equity offerings. Journal of Accounting and Economics, 50(1), 2-19. https://doi.org/10.1016/j.jacceco.2010.01.002

Cohen, D. A., Dey, A., \& Lys, T. Z. (2008). Real and accrual-based earnings management in the pre-and $\begin{array}{lllll}\text { post-Sarbanes-Oxley } & \text { 7heriods. }\end{array}$ https://doi.org/10.2308/accr.2008.83.3.757

Dalton, D. R., Daily, C. M., Johnson, J. L., \& Ellstrand, A. E. (1999). Number of directors and financial performance: A meta-analysis. Academy of Management Journal, 42(6), 674-686. https://doi.org/10.2307/256988

Dechow, P. M., \& Schrand, C. M. (2004). Earnings quality. Charlottesville, VA: CFA Institute.

Ding, Y., Zhang, H., \& Zhang, J. (2007). Private vs state ownership and earnings management: Evidence from Chinese listed companies. Corporate Governance: An International Review, 15(2), 223-238. https://doi.org/10.1111/j.1467-8683.2007.00556.x

Fama, E., \& Jensen, M. (1983). Separation of ownership and control. Journal of Law and Economics, 26(2), 301-325. https://doi.org/10.1086/467037

Fields, T. D., Lys, T. Z., \& Vincent, L. (2001). Empirical research on accounting choice. Journal of Accounting and Economics, 31(1-3), 255-273. https://doi.org/10.1016/S0165-4101(01)00028-3

Finkelstein, S., \& D'aveni, R. A. (1994). CEO duality as a double-edged sword: How boards of directors balance entrenchment avoidance and unity of command. Academy of Management Journal, 37(5), 1079-1108. https://doi.org/10.5465/256667

García - Meca, E., \& Sánchez-Ballesta, J. P. (2009). Corporate governance and earnings management: A meta analysis. Corporate Governance: an International Review, 17(5), 594-610. https://doi.org/10.1111/j.1467-8683.2009.00753.x

Gillan, S. L., \& Starks, L. T. (2000). Corporate governance proposals and shareholder activism: the role of institutional investors. Journal of Financial Economics, 57(2), 275-305. https://doi.org/10.1016/S0304-405X(00)00058-1

Graham, J. R., Harvey, C. R., \& Rajgopal, S. (2005). The economic implications of corporate financial reporting. Journal of Accounting and Economics, 40(1-3), 3-73. https://doi.org/10.1016/j.jacceco.2005.01.002 
Gu, Z., Lee, C. W. J., \& Rosett, J. G. (2005). What determines the variability of accounting accruals?. Review of Quantitative Finance and Accounting, 24(3), 313-334. https://doi.org/10.1007/s11156-005-6869-1

Haji-Abdullah, N. M., \& Wan-Hussin, W. N. (2015). Related party transactions, audit committees and real earnings management: The moderating impact of family ownership. Advanced Science Letters, 21(6), 2033-2037. https://doi.org/10.1166/asl.2015.6195

Har Sani Mohamad, M., Majdi Abdul Rashid, H., \& Ali Mohammed Shawtari, F. (2012). Corporate governance and earnings management in Malaysian government linked companies: The impact of GLCs' transformation policy. Asian Review of Accounting, 20(3), 24-258. https://doi.org/10.1108/13217341211263283

Healy, P. M., \& Wahlen, J. M. (1999). A review of the earnings management literature and its implications for standard setting. Accounting Horizons, 13(4), 365-383. https://doi.org/10.2308/acch.1999.13.4.365

Hermalin, B. E., \& Weisbach, M. S. (2001). Boards of directors as an endogenously determined institution: A survey of the economic literature (No. w8161). National Bureau of Economic Research. https://doi.org/10.3386/w8161

Hoang, T., Abeysekera, I., \& Ma, S. (2014). State ownership and earnings management: empirical evidence from Vietnamese listed firms. Proceedings of the 1st International Conference on Finance and Economics 2014 (pp.257-268). Zlin, Czech Republic, Tomas Bata University.

Jamaludin, N. D., Sanusi, Z. M., \& Kamaluddin, A. (2015). Board Structure and Earnings Management in Malaysian Government Linked Companies. Procedia Economics and Finance, 28, 235-242. https://doi.org/10.1016/S2212-5671(15)01105-3

Jensen, M. (1993). The modern industrial revolution: Exit and failure of internal control systems. Journal of Finance, 48, 831-880. https://doi.org/10.1111/j.1540-6261.1993.tb04022.x

Jensen, M., \& Meckling, W. (1976). Theory of the firm: Managerial behavior, agency costs, and ownership structure. Journal of Financial Economics, 3(4), 305-360. https://doi.org/10.1016/0304-405X(76)90026-X

Jow, W. Y., Loo, S. C., Zainal Abidin, S., Noordin, A., \& Ariffin, B. (2007). Earnings management practices between government linked and Chinese family linked companies. International Journal of Economics and Management, 1(3), 387-406.

Koh, P. (2007). Institutional investor type, earnings management and benchmark beaters. Journal of Accounting and Public Policy, 26(3), 267-299. https://doi.org/10.1016/j.jaccpubpol.2006.10.001

Lau, Y. W., \& Tong, C. Q. (2008). Are Malaysian government-linked companies (GLCs) creating value. International Applied Economics and Management Letters, 1(1), 9-12.

Lipton, M., \& Lorsch, J. W. (1992). A modest proposal for improved corporate governance. The Business Lawyer, 59-77.

Mohd Ghazali, N. A. (2007). Ownership structure and corporate social responsibility disclosure: some Malaysian evidence. Corporate Governance: The International Journal of Business in Society, 7(3), 251-266. https://doi.org/10.1108/14720700710756535

Morgan, B. M., \& Alcocer, L. F. (2017). Descriptive Comparison of Hispanic Doctoral Students (2007-2014) with Carnegie Initiative of the Doctorate National Survey Results. American Journal of Education and Learning, 2(1), 14-22. https://doi.org/10.20448/804.2.1.14.22

Moussa, A. (2018). Does Agricultural Sector Contribute to the Economic Growth in Case of Republic of Benin?. Journal of Social Economics Research, 5(2), 85-93. https://doi.org/10.18488/journal.35.2018.52.85.93

Mungwari, T. (2018). Centre for Language and Communication Studies, Chinhoyi University of Technology, Zimbabwe. International Journal of Social Sciences Perspectives, 2(2), 112-125. https://doi.org/10.33094/7.2017.2018.22.112.125

Myeni, S. L., \& Mvuyana, B. Y. (2018). Participatory Processes in Planning for Self-Help Housing Provision in South Africa: Policies and Challenges. International Journal of Public Policy and Administration Research, 5(1), 24-36.

Nejad, M. A. R. S., Agha, F. N. J., \& Zadeh, Y. F. (2017). QSPM Usage in SWOT Analysis as a Tool for Strategic Management of Caspian Sea Coasts (Case Study: Tourism Development in Caspian Eastern Coast at Gilan Province). Journal of Tourism Management Research, 4(1), 1-11. https://doi.org/10.18488/journal.31.2017.41.1.11 
Nxumalo, N. L., \& Naidoo, L. D. (2018). A Case Study of Local Government Implementation of the Ward Based Local Economic Development (LED) Program. International Journal of Public Policy and Administration Research, 5(1), 1-23. https://doi.org/10.18488/journal.74.2018.51.1.23

Osma, B. G. (2008). Board independence and real earnings management: The case of R\&D expenditure. Corporate Governance: An International Review, 16(2), 116-131. https://doi.org/10.1111/j.1467-8683.2008.00672.x

Peasnell, K. V., Pope, P. F., \& Young, S. (2005). Board monitoring and earnings management: Do outside directors influence abnormal accruals?. Journal of Business Finance \& Accounting, 32(7-8), 1311-1346. https://doi.org/10.1111/j.0306-686X.2005.00630.x

Roychowdhury, S. (2006). Earnings management through real activities manipulation. Journal of Accounting and Economics, 42, 335-370. https://doi.org/10.1016/j.jacceco.2006.01.002

Saleh, N. M., Iskandar, T. M., \& Rahmat, M. M. (2005). Earnings management and board characteristics: Evidence from Malaysia. Jurnal Pengurusan, 24(4), 77-103.

Salleh, M. F. (2009). Political influence, corporate governance and financial reporting quality: Evidence from companies in Malaysia. Doctoral thesis, Massey University, New Zealand.

Suffian, M., Taufik, M., Mohd Sanusi, Z., \& Mastuki, N. A. (2015). Real earnings management and firm value: Empirical evidence from Malaysia/Mohd Taufik Mohd Suffian, Zuraidah Mohd Sanusi and Nor'Azam Mastuki. Malaysian Accounting Review, 14(1), 26-47.

Sulong, Z., Sanusi, Z. M., \& Ibrahim, M. T. (2014). Opportunistic behaviour in Malaysian public listed companies: The relationship between earnings management through real activity manipulation and management incentive. The Global Journal of Finance and Economics, 11(2), 203-218.

Vicknair, D., Hickman, K., \& Carnes, K. C. (1993). A note on audit committee independence: Evidence from the NYSE on" grey" area directors. Accounting Horizons, 7(1), 53-57.

Wahab, E. A. A., How, J. C., \& Verhoeven, P. (2007). The impact of the Malaysian code on corporate governance: Compliance, institutional investors and stock performance. Journal of Contemporary Accounting \& Economics, 3(2), 106-129. https://doi.org/10.1016/S1815-5669(10)70025-4

Wang, J. (2002). Governance role of different types of state shareholders: evidence from China's listed companies. Working paper, The Hong Kong University of Science and Technology.

Wang, L., \& Yung, K. (2011). Do state enterprises manage earnings more than privately owned firms? The case of China. Journal of Business Finance \& Accounting, 38(7-8), 794-812. https://doi.org/10.1111/j.1468-5957.2011.02254.x

Watts, R. L., \& Zimmerman, J. L. (1978). Towards a positive theory of the determination of accounting standards. Accounting Review, 53(1), 112-134.

Xie, B., Davidson, W. N., \& DaDalt, P. J. (2003). Earnings management and corporate governance: the role of the board and the audit committee. Journal of Corporate Finance, 9(3), 295-316. https://doi.org/10.1016/S0929-1199(02)00006-8

Zamri, N., Rahman, R. A., \& Isa, N. S. M. (2013). The impact of leverage on real earnings management. Procedia Economics and Finance, 7, 86-95. https://doi.org/10.1016/S2212-5671(13)00222-0 